\title{
Kuliah Kerja Nyata (KKN) sebagai Metode Pembelajaran di Fakultas Kedokteran Universitas YARSI
}

\section{The Community Service Program Activity as a Learning Method at YARSI University Faculty of Medicine}

\author{
Miranti Pusparini \\ YARSI University, Faculty of Medicine, Jakarta \\ Correspondence Email: miranti.pusparini@yarsi.ac.id
}

\begin{abstract}
Abstrak
Sehubungan dengan adanya peraturan SNPT no 44 tahun 2015, bentuk pembelajaran pendidikan diploma empat, program sarjana, program profesi, dan program spesialis wajib ditambah pembelajaran berupa pengabdian kepada masyarakat. Dalam rangka mencoba menerapkan bentuk pembelajaran pengabdian masyarakat, Universitas YARSI bekerjasama dengan Dinas Perlindungan Anak dan Pemberdayaan Perempuan (DPPAPP) melaksanakan kegiatan Kuliah Kerja Nyata (KKN) Program Kependudukan dan Keluarga Berencana serta Pembangunan Keluarga (KKBPK). KKN dilaksanakan pada proses pembelajaran di Fakultas Kedokteran Universitas YARSI semester 7 (tujuh) tahun ajaran 2017 - 2018 dalam Blok Elektif dengan peminatan Kekerasan Dalam Rumah Tangga (KDRT), dilakukan oleh 1 kelompok yang terdiri dari 5 (lima) orang mahasiswa sebagai pemateri. Bentuk kegiatan berupa penyuluhan dengan pretest dan posttest serta diskusi. Pretes dan postes diberikan sebagai tolok ukur penyampaian materi. Hasil pretes menunjukan nilai yang baik (80-90) sebanyak 7 orang atau sekitar $29,17 \%$, nilai cukup (antara 60-70) sebanyak 10 orang atau sekitar $41,67 \%$, dan nilai kurang ( $\leq 50$ ) sebanyak 7 orang atau sekitar $29,17 \%$. Hasil post tes menunjukan nilai yang baik (antara 80-100) sebanyak 12 orang atau sekitar 48\%, nilai cukup (antara 60-70) sebanyak 9 orang atau sekitar $36 \%$, dan nilai yang kurang sebanyak 4 orang atau sekitar $16 \%$. Kuesioner penilaian pelaksanaan kegiatan penyuluhan juga disebarkan, dengan hasil pemateri $58,14 \%$ dinilai sangat baik, dan untuk materi penyuluhan $48,84 \%$ dinilai baik.Terlihat peningkatan rerata nilai secara umum sebanyak 12,38 poin yang semula 60,42 saat pretes menjadi 72,80 saat postes. Hal ini menunjukan bahwa materi penyuluhan dapat tersampaikan dengan baik oleh seluruh mahasiswa.
\end{abstract}

Kata kunci: SNPT, KKN, pengabdian masyarakat, mahasiswa 


\begin{abstract}
According to SNPT no 44, 2015 , for diploma education, undergraduate, professional, and specialist programs must be added community service. To apply the form of community service learning, YARSI University in collaboration with Dinas Perlindungan Anak dan Pemberdayaan Perempuan (DPPAPP) conducted Community Service Program from Program Kependudukan dan Keluarga Berencana serta Pembangunan Keluarga (KKBPK). The Community Service Program activity is carried out in the learning process in the 7th semester at the Faculty of Medicine YARSI University academic year of 2017 - 2018, in Elective Block with Domestic Violence interest. This activity conducted by 1 group consisting of 5 (five) students as counselor, whom give counseling and discussion. Pre test and post test are given as benchmarks of the delivery of the material. The results of pretest showed 7 participants or $29.17 \%$ got $80-90$ points, 10 participants or $41.67 \%$ got $60-70$ points, and 7 participants got $\leq 50$ points. Post test showed 12 participants or $48 \%$ got 80-100 points, 9 participants or $36 \%$ got $60-70$ points, and only 4 participants or $16 \%$ got $\leq 50$ points. Questionnaires for the assessment showed that 58,14\% presentation was considered very good, and for the presentation material $48,84 \%$ was considered good. The result showed the increase of average score 12.38 points from 60.42 on pretest to 72.80 at post test. This shows that the material can be well delivered by all students. The results of questionnaires showed that the students can delivered the material very well, and the material provided by the students was considered good.
\end{abstract}

Keyword: SNPT, Community Service Program Activity, students

\section{Introduction}

Lerning form according to Standar Nasional Pendidikan Tinggi/SNPT (National Standards of Higher Education) number 44 of 2015, consists of lectures, responses and tutorials, seminars, and practicum, studio practice, workshop practice, or field practice. For diploma education, undergraduate, professional, and specialist programs must be added community service, a student activity under the guidance of lecturers in order to utilize science and technology to advance the welfare of society and educate the nation. Community service activities undertaken by students as one of the forms of learning should be directed to meet the achievements of learning outcome and regulatory requirements in universities. The minimum criteria for assessment of the results of community service include: a. level of community satisfaction; b. changes in attitudes, knowledge, and skills to the community in accordance with program objectives; c. sustainable use of science and technology in society; $d$. the creation of enrichment of learning resources and / or learning as well as the maturation of the academic community as a result of the development of science and technology; or e. the limitation of social issues and policy recommendations that stakeholders can take advantage of.

Community Service Program Activity is an intracurricular activity that combines Tridharma of the Higher Education. Tri Dharma of the Higher Education according to UndangUndang Republik Indonesia Nomor 12 Tahun 2012 Tentang Pendidikan Tinggi (Law of the 
Republic of Indonesia number 12 of 2012 on Higher Education) is the obligation of Higher Education to organize education, research, and community service. Community Service is the activity of academic community that utilize science and technology to advance people's prosperity and educate the life of the nation. Community Service Program Activity is one form of the implementation of community service in Tridharma of the Higher Education. The implementation of community service is done in accordance with the academic culture, expertise, and / or academic autonomy of the academic community as well as the socio-cultural conditions of the community.

Community Service Program Activity implementation is to provide stock to students in the form of learning experiences and community empowerment. Community service activities become a good choice as a tools for socialization of development programs, including Family Planning and Family Development. Increasing the role of Community Service Program Activity students in disseminating Family Planning and Family Development, will provide double benefit, that is for the students themselves to be more understanding about Population issues, Family Planning, and Family Development, as well as for communities in Community Service Program Activity locations that get explanation from Community Service Program Activity students. The students can be a medium of socialization to the community, community mobilizer, and become a community-based example.

One of the theme of Community Service Program Activity conducted by DPPAPP is Child Care, Domestic Violence, Gender Equality and Justice. Domestic Violence according to the Law of the Republic of Indonesia number 23 of 2004 on the Abolition of Domestic Violence is any act against a person, especially women, resulting in misery or suffering physically, sexually, psychologically, or destruction of household expenses including threat to commit acts, coercion, or deprivation of liberty unlawfully within the scope of the household. According to the annual report of the National Commission of Women during 2016 there were 259,150 cases of reported and handled violence against women, consisting of 245,548 cases sourced from cases / cases data handled by 359 Religious Courts, and 13,602 cases handled by 233 service provider partners, spread over 34 Provinces. While in 2017 there were 348,446 cases of reported and handled violence against women, consisting of 335,062 cases sourced from case / case data handled by Religious Courts, and 13,384 cases handled by 237 partner service agencies spread over 34 Provinces. In general there is an increase in cases of domestic violence, or an increase in reporting the incidence of domestic violence. National Commission on Women states that Jakarta occupies the first position of the area that often happened cases of violence against women during 2016. Jakarta occupies the first position with 2,552 cases, followed by East Java 1635 cases, West Java 1.377 cases, and Central Java 1.123 cases. National Commission on Women received reports of violent complaints from various parties, ranging from economy, age, religion, ethnicity, education, and profession. From all the 13,602 cases of violence, $75 \%$ or 10,205 cases of violence occurred in the personal realm, namely domestic violence. The rest is done in the community sphere with $23 \%$ or 3,092 cases, and the state sphere with 305 cases. While in the community, the highest rape, and occurred in employment, in education, also experienced by migrant workers. Sexual violence 
was first ranked to 2,290 cases, followed by physical violence 490 cases and other violence, 83 cases of psychological violence, migrant workers 90 cases and trafficking 139 cases.

Community Service Program Activity in YARSI University's Medical Faculty has never been implemented before. To apply the form of community service learning, YARSI University in collaboration with Dinas Perlindungan Anak dan Pemberdayaan Perempuan/DPPAPP (The Office of Child Protection and Women's Empowerment) conducted Community Service Program Activity from Program Kependudukan dan Keluarga Berencana serta Pembangunan Keluarga/KKBPK (Population and Family Planning and Family Development Program). With the collaboration with DPPAPP, Community Service Program Activity is attempted to be implemented in Elective Block for $7^{\text {th }}$ semester students. The Elective Block has been running since 2007 curriculum, consists of several interests such as emergency, drugs, palliative care, and domestic violence. Elective block is implemented in 3 weeks, students are formed in small groups according to their intrest. Furthermore, each student will take one case according to the location of intrest such as Pasar Rebo Hospital for emergency, National Narcotics Agency for drug abuse, Dharmais Cancer Hospital for palliative care, and Legal Aid Institute for the domestic violence intrest. Students then develop case reports with a review of social, legal, psychological, management, and Islamic views.

Domestic violence in this case is one of the special concerns of DPPAPP. Student activities through this Community Service Program Activity aims to provide an overview of current and future population conditions of Indonesia and the importance of population data.
In addition, it also helps families and communities to develop their potentials optimally for their own interests and the wider environment. Students through this area of interest can learn and analyze issues related to violence against women, violence against children, as well as about various forms of personality in the family, as well as on gender equality. At the end of the activity, it is expected to increase understanding of domestic violence and gender equality, so as to improve the quality of family welfare.

\section{Research Methodology}

The Community Service Program activity is carried out in the learning process in the $7^{\text {th }}$ semester at the Faculty of Medicine YARSI University academic year of 2017 - 2018, in Elective Block with Domestic Violence interest which runs from October to November 2017. This activity conducted by 1 group consisting of 5 (five) students as counselor, whom give counseling and discussion, accompanied by a Lecturer. The activities carried out in Kampung Keluarga Berencana (Family Planning Village) in the area of DPPAPP of DKI Jakarta Province. This activity was held in Ruang Publik Terbuka Terpadu Ramah Anak/RPTRA (Child Friendly Open Space Public Room) Pulo Gundul on Friday, October 27, 2017. The target of this activity is 50 people of productive age group (15 - 64 years), especially for women.

The activities were conducted with counseling and discussion for productive age group, as well as assistance for the victims. Counseling and discussions were conducted by students, beginning and ending with pretest and postes, and distributing questionnaires for student counseling assessments. Students present the material using the power point that 
has been prepared and approved by the supervisor.

The given pretest and postes consist of 10 questions referring to the given material. The question given on the pretest is the same as the question given at postes. Of the total 50 participants, only 25 participants were collected.
The student counseling assessment questionnaire is filled out by the participants, consisting of material ratings and an assessment of the delivery of materials. Assessment is made on a scale of 1 - 4, which has the meaning of poor, fair, good, and excellent. Of the total 50 participants, only 25 participants were collected.

Table 1. Students Material

\begin{tabular}{|l|l|l|l|}
\hline No. & \multicolumn{1}{|c|}{ Name } & \multicolumn{1}{|c|}{ NPM } & \multicolumn{1}{c|}{ Material } \\
\hline 1. & Martiana Fahriah & 1102014151 & The Impact of Domestic Violence on Children \\
\hline 2. & Olvie Astanaini Annisa & 1102014205 & Jealousy as a Cause of Domestic Violence \\
\hline 3. & Putri Justicarici & 1102014213 & Domestic Violence from the Legal Viewpoint \\
\hline 4. & Nora Saputri & 1102014197 & Domestic Violence in Islamic Views \\
\hline 5. & Optaviana & 1102014201 & Prevention and Handling of Domestic Violence \\
\hline
\end{tabular}

Table 2. Participants Pretest and Postes Results

\begin{tabular}{|c|c|c|c|}
\hline No & Pretest & Postes & Enhancement \\
\hline 1. & 90 & 90 & 0 \\
\hline 2. & 70 & 70 & 0 \\
\hline 3. & 70 & 80 & 10 \\
\hline 4. & 70 & 80 & 10 \\
\hline 5. & 60 & 80 & 20 \\
\hline 6. & 60 & 60 & 0 \\
\hline 7. & 60 & 90 & 30 \\
\hline 8. & 50 & 60 & 10 \\
\hline 9. & 20 & 40 & 20 \\
\hline 10. & 40 & 60 & 20 \\
\hline 11. & 80 & 80 & 0 \\
\hline 12. & 80 & 70 & -10 \\
\hline 13. & 90 & 90 & 0 \\
\hline 14. & 80 & 100 & 20 \\
\hline 15. & 60 & 100 & 40 \\
\hline 16. & 10 & 50 & 40 \\
\hline 17. & 0 & 70 & 70 \\
\hline 18. & 70 & 70 & 0 \\
\hline 19. & 50 & 60 & 10 \\
\hline 20. & 20 & 40 & 20 \\
\hline 21. & 60 & 70 & 10 \\
\hline 22. & 80 & 90 & 10 \\
\hline 23. & 40 & 50 & 10 \\
\hline 24. & 80 & 90 & 10 \\
\hline 25. & 60 & 80 & 20 \\
\hline & 60.42 & $\mathbf{7 2 . 8 0}$ & $\mathbf{1 2 . 3 8}$ \\
\hline & & & \\
\hline
\end{tabular}


Tabel 3. Questionnaires for Student Counseling Assessments Result

\begin{tabular}{|c|c|c|c|}
\hline No & Questionaire & Percentage & Conclusion \\
\hline 1. & Assessment of the counselor & & \\
\hline a. & Martiana Fahriah & & \\
\hline & 1 Poor & $0.00 \%$ & \multirow{4}{*}{ Good } \\
\hline & 2 Fair & $20.93 \%$ & \\
\hline & 3 Good & $41.86 \%$ & \\
\hline & 4 Very Good & $34.88 \%$ & \\
\hline b. & Olvie Astanaini Annisa & & \\
\hline & 1 Poor & $0.00 \%$ & \multirow{4}{*}{ Very Good } \\
\hline & 2 Fair & $16.28 \%$ & \\
\hline & 3 Good & $41.86 \%$ & \\
\hline & 4 Very Good & $41.86 \%$ & \\
\hline c. & Putri Justicarici & & \\
\hline & 1 Poor & $0.00 \%$ & \multirow{4}{*}{ Very Good } \\
\hline & 2 Fair & $16.28 \%$ & \\
\hline & 3 Good & $25.58 \%$ & \\
\hline & 4 Very Good & $58.14 \%$ & \\
\hline d. & Nora Saputri & & \multirow{5}{*}{ Very Good } \\
\hline & 1 Poor & $0.00 \%$ & \\
\hline & 2 Fair & $18.60 \%$ & \\
\hline & 3 Good & $39.53 \%$ & \\
\hline & 4 Very Good & $41.86 \%$ & \\
\hline e. & Optaviana & & \\
\hline & 1 Poor & $0.00 \%$ & \multirow{4}{*}{ Good } \\
\hline & 2 Fair & $13.95 \%$ & \\
\hline & 3 Good & $46.51 \%$ & \\
\hline & 4 Very Good & $39.53 \%$ & \\
\hline 2. & Assessment of materials & & \\
\hline a. & The Impact of Domestic Violence on Children & & \\
\hline & 1 Poor & $0.00 \%$ & \multirow{4}{*}{ Good } \\
\hline & 2 Fair & $13.95 \%$ & \\
\hline & 3 Good & $48.84 \%$ & \\
\hline & 4 Very Good & $37.21 \%$ & \\
\hline b. & Jealousy as a Cause of Domestic Violence & & \\
\hline & 1 Poor & $0.00 \%$ & \multirow{4}{*}{ Good } \\
\hline & 2 Fair & $6.98 \%$ & \\
\hline & 3 Good & $48.84 \%$ & \\
\hline & 4 Very Good & $44.19 \%$ & \\
\hline c. & Domestic Violence from the Legal Viewpoint & & \\
\hline & 1 Poor & $0.00 \%$ & \multirow{4}{*}{ Good } \\
\hline & 2 Fair & $6.98 \%$ & \\
\hline & 3 Good & $46.51 \%$ & \\
\hline & 4 Very Good & $39.53 \%$ & \\
\hline d. & Domestic Violence in Islamic Views & & \multirow{5}{*}{ Good } \\
\hline & 1 Poor & $0.00 \%$ & \\
\hline & 2 Fair & $6.98 \%$ & \\
\hline & 3 Good & $48.84 \%$ & \\
\hline & 4 Very Good & $44.19 \%$ & \\
\hline e. & Prevention and Handling of Domestic Violence & & \\
\hline & 1 Poor & $0.00 \%$ & \multirow{4}{*}{ Good } \\
\hline & 2 Fair & $9.30 \%$ & \\
\hline & 3 Good & $46.51 \%$ & \\
\hline & 4 Very Good & $41.86 \%$ & \\
\hline
\end{tabular}




\section{Discussion}

Pretes and postes are given as benchmarks of the delivery of the material. The given pretest and postes consist of 10 questions referring to the given material. The question given on the pretest is the same as the question given at postes. Of the total 50 participants, only 25 participants were collected. The results of pretest showed 7 participants or $29.17 \%$ got 80 90 points, 10 participants or $41.67 \%$ got $60-70$ points, and 7 participants got $\leq 50$ points. Postes results showed 12 participants or $48 \%$ got $80-100$ points, 9 participants or $36 \%$ got 60 70 points, and only 4 participants or $16 \%$ got $\leq$ 50 points. After the counseling, postes results showed an average increase in the average score of 12.38 points from 60.42 when pretest to 72.80 at postes. This indicates that the materials can be well communicated by all the speakers, and there is an increasing knowledge about domestic violence held by participants.

The student counseling assessment questionnaire is filled out by the participants, consisting of material ratings and an assessment of the delivery of materials. Assessment is made on a scale of $1-4$, which has the meaning of poor, fair, good, and excellent. Of the total 50 participants, only 25 participants were collected. Questionnaires for the assessment of the implementation showed that $58,14 \%$ presentation was considered very good, and for the presentation material $48,84 \%$ was considered good. This shows that the material given and the way of delivering the material is adequate and required by the participants.

\section{Conclusion}

The test result showed the increase of average score 12.38 points from 60.42 on pretest to 72.80 at postes. This shows that the material can be well delivered by all students and there is an increasing knowledge about domestic violence held by participants and at the end of the activity, it is expected to increase understanding of domestic violence and gender equality, so as to improve the quality of family welfare.

The results of questionnaires showed that all the participants rate that the students can delivered the material very well, and the material provided by the students was considered good. This activity gives students the opportunity to apply the knowledge they have so far, also apply the ability to make presentations and educate the community directly. The results of the questionnaire showed that the students were able to interact with the community and be able to apply their knowledge and skills. Students directly perform community service as the realization of the tridarma of the higher education.

Community service activities that have been done by the students is one of the forms of learning that is geared to meet the learning outcomes. The Community Service Program Activity also showed that students can be a medium of socialization to the community, community mobilizer, and become a communitybased example. This activity also results in community satisfaction; changes in attitudes, knowledge, and skills to the community in accordance with program objectives; sustainable use of science and technology in society; the creation of enrichment of learning resources and I or learning as well as the 
maturation of the academic community as a result of the development of science and technology; as well as the limitation of social issues and policy recommendations that stakeholders can take advantage of. The results of this activity in accordance with the expected results in the standard implementation of community service according to the National Higher Education Standard number 44 of 2015.

\section{Take Home Message}

The Community Service Program activities are expected to continue, to increase knowledge in the community, as well as to increase the ability of students, as well as provide opportunities for students to have early direct learning experience in the community. Community service activities that can be implemented can include: community services; application of science and technology in accordance with their area of expertise; community capacity building; or community empowerment. Furthermore, community service activities undertaken by students as one of the forms of learning should be directed to meet the achievement of learning outcome.

\section{Reference}

BPS Statistic for Jakarta Province, 2016. "Jakarta in Figures 2016". BPS-Statistics of DKI Jakarta Province

Fakultas Kedokteran Universitas YARSI, 2017. "Buku Panduan Blok Elektif". Pusat Pendidikan Kedokteran FKUY

Lembar Fakta Catatan Tahunan (CATAHU) Komnas Perempuan, 2017. "Labirin Kekerasan terhadap Perempuan: Dari Gang Rape hingga Femicide, Alarm bagi Negara untuk Bertindak Tepat”. Maret 2017

Lembar Fakta dan Poin Kunci Catatan Tahunan (CATAHU) Komnas Perempuan Tahun 2018. 'Tergerusnya Ruang Aman Perempuan dalam Pusaran Politik Populisme'. Maret 2018

Moeliono L, Hasyim E, 2014. "Buku Saku Kegiatan KKN Mahasiswa". Direktorat Kerjasama Pendidikan Kependudukan BKKBN

Peraturan Menteri Riset, Teknologi, Dan Pendidikan Tinggi Republik Indonesia Nomor 44 tahun 2015 Tentang Standar Nasional Pendidikan Tinggi

Undang-Undang Republik Indonesia Nomor 23 Tahun 2004 Tentang Penghapusan Kekerasan Dalam Rumah Tangga Undang-Undang Republik Indonesia Nomor 12 Tahun 2012 Tentang Pendidikan Tinggi 


\section{Attachment}

PRETEST and POSTES questions

1. Seorang ibu memukul anaknya ketika sedang marah, tindakan yang dilakukan oleh Ibu tersebut adalah.
a. Kekerasan psikis
b. Kekerasan fisik
c. Kekerasan ekonomi
d. Kekerasan seksual

2. Terdapat dampak dari kekerasan yang dilakukan oleh pelaku kepada korban dibawah ini, kecuali...
a. Trauma
b. Merasa sakit
c. Paranoid
d. Merasa disayangi

3. Emotional Jelously, Kecemburuan yang melibatkan....
a. Perasaan dan rasa amarah
b. Rasa curiga yang berlebihan terhadap pasangan
c. Rasa protektif dan dekektif yang berlebihan
d. Tidak peduli pada pasangan

4. Berikut adalah tips untuk mengurangi rasa cemburu, kecuali.....
a. Mendekatkan diri dari Tuhan
b. Saling percaya
c. Pengertian terhadap pasangan
d. Berdandan secara berlebihan agar terlihat lebih cantik

5. Di atur dalam Undang-undang nomor Berapa perlindungan hukum terhadap korban kekerasan dalam rumah tangga...
a. UU nomor 23 tahun 2004
b. UU nomor 33 tahun 2006

c. UU nomor 23 tahun 2006

d. UU nomor 33 tahun 2004

6. Apakah sanksi yang diberikan kepada pelaku kekerasan fisik dalam rumah tangga...
a. Penjara paling lama 5 tahun dengan denda 15juta rupiah
b. Penjara paling lama 2 tahun dengan denda 10juta rupiah
c. Penjara paling lama 8 tahun dengan denda 15 juta rupiah
d. Penjara paling lama 5 tahun dengan denda 10juta rupiah

7. Yang termasuk batasan diperbolehkannya melakukan pemukulan adalah...
a. Pukulan yang menyakitkan
b. Pukulan yang ringan
c. Pukulan dalam keadaan emosi
d. Pukulan untuk anak yang dibawah umur 10 tahun

8. Firman Allah yang menyebutkan bahwa seorang istri mempunyai hak untuk diberi nafkah, mendapatkan kasih sayang, terdapat dalam surat..
a. Al baqarah ayat 128
b. Al baqarah ayat 28
c. An nisa ayat 128
d. Al baqarah ayat 228

9. Dibawah ini yang termasuk pencegahan KDRT adalah....
a. Menjauhkan diri pada Tuhan
b. Boleh berkata kasar pada anak
c. Komunikasi yang baik
d. Menyelesaikan masalah secara sepihak


10. Apabila kita melihat KDRT di lingkungan kita, yang lakukan sebagai orang terdekat adalah...

a. Diam saja b. Melapor pada RT

c. Melerai

d. Melapor pada pihak yang berwajib 
Questionaire Form

\begin{tabular}{|c|l|c|c|c|c|}
\hline No & \multicolumn{1}{|c|}{ Questionaire } & $\mathbf{1}$ & $\mathbf{2}$ & $\mathbf{3}$ & $\mathbf{4}$ \\
\hline 1. & Assessment of the counselor & & & & \\
\hline a. & Martiana Fahriah & & & & \\
\hline b. & Olvie Astanaini Annisa & & & & \\
\hline c. & Putri Justicarici & & & \\
\hline d. & Nora Saputri & & & & \\
\hline e. & Optaviana & & & & \\
\hline 2. & Assessment of materials & & & \\
\hline a. & The Impact of Domestic Violence on Children & & \\
\hline b. & Jealousy as a Cause of Domestic Violence & & \\
\hline c. & Domestic Violence from the Legal Viewpoint & & & \\
\hline d. & Domestic Violence in Islamic Views & & \\
\hline e. & Prevention and Handling of Domestic Violence & & & & \\
\hline & & & & \\
\hline
\end{tabular}


Community Service Program Activity

RPTRA Pulo Gundul

Friday, October $27^{\text {th }}, 2017$
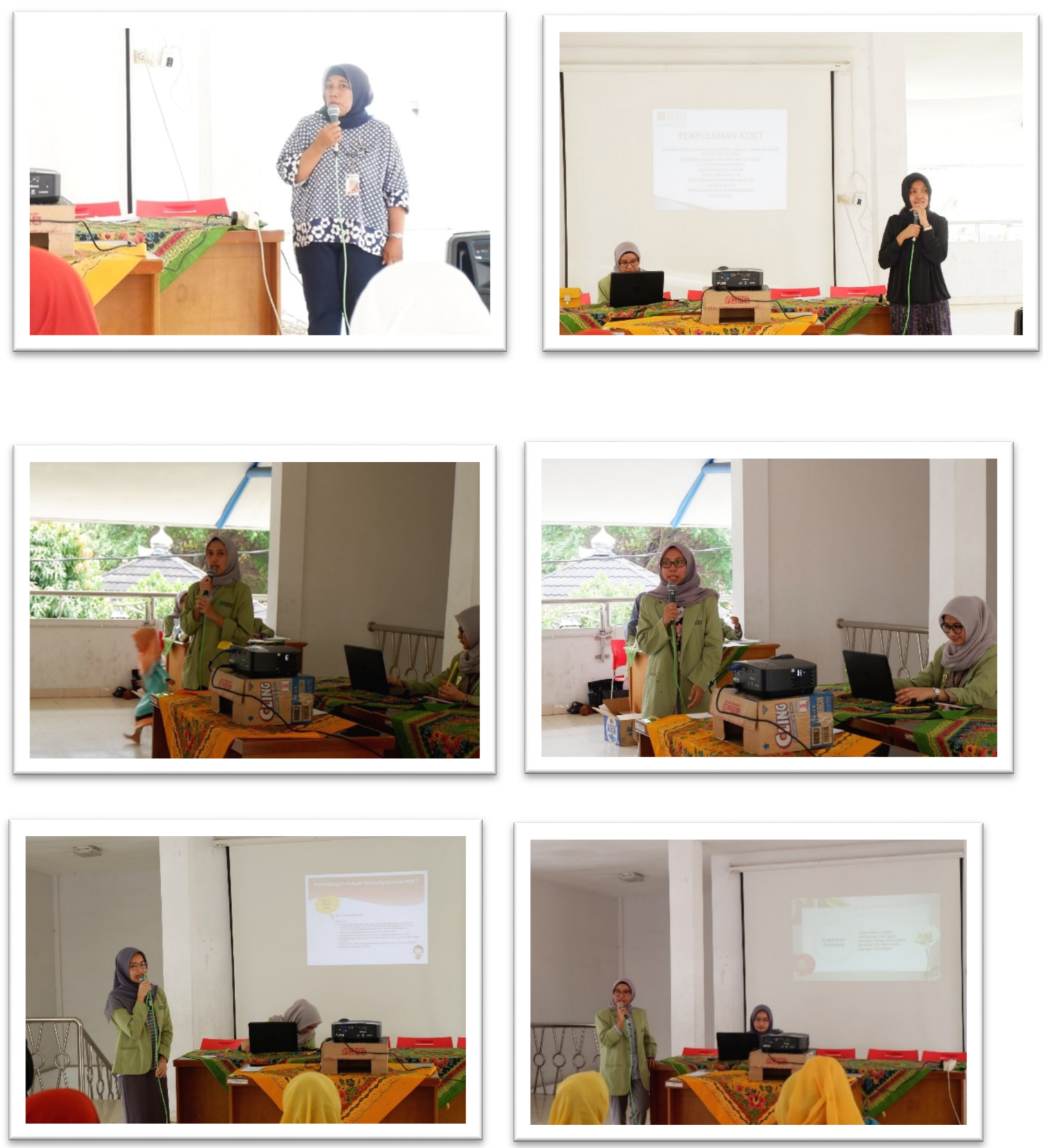

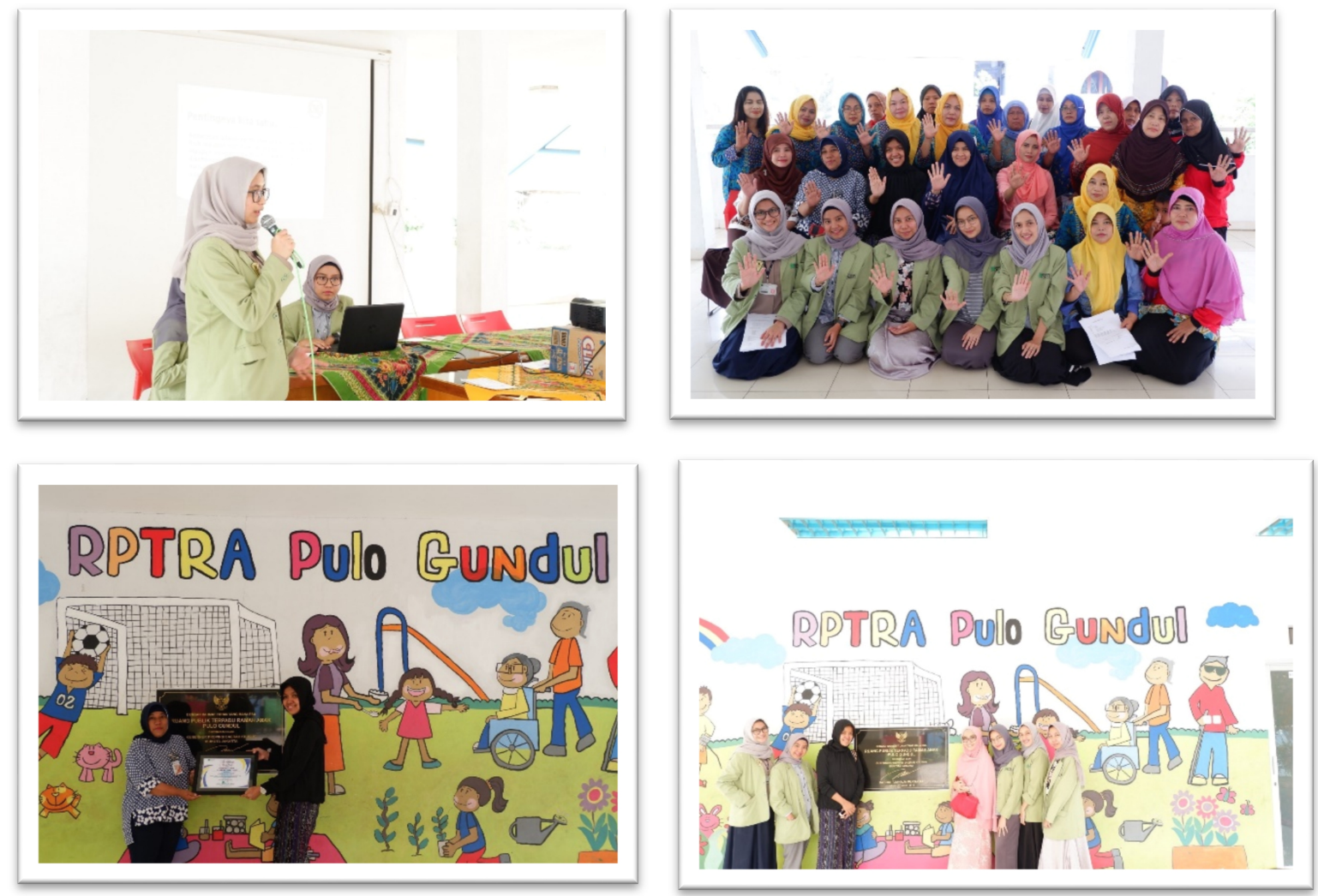